\title{
PRAKTIK HIGIENE PERORANGAN DAN SANITASI WARUNG PECEL TUMPANG DI KOTA KEDIRI
}

\author{
Personal Hygiene PracticeandFood Stalls SanitationofPecel TumpanginKediri City \\ ${ }^{1}$ Gading Giovani Putri, 2 Yoanita Indra Kumala Dewi \\ ${ }^{1}$ Staff Pengajar S1 Kesehatan Masyarakat, Institut Ilmu Kesehatan Bhakti Wiyata Kediri, \\ ${ }^{2}$ Staff Pengajar D3 Analis Kesehatan, Institut Ilmu Kesehatan Bhakti Wiyata Kediri, \\ email: gadinggiovani@gmail.com
}

\begin{abstract}
To realize food safety is applying good personal hygiene and sanitation.This study aims to describe personal hygiene and foodstalls sanitation of pecel tumpang in Kediri.An observational study with cross sectional design done on 20 sampels. Data performed in table with descriptive analyzed. Most of respondents had quite personal hygiene (80\%), good location and building (50\%), poor waste disposal (50\%), poor sanitation facilities(50\%), good sanitation of equipments (100\%), and good clean water (90\%).Somevariables indicate poor sanitation i.e. waste disposal and sanitation facilities.
\end{abstract}

Keywords: personal hygiene, food stalls sanitation, pecel tumpang

\begin{abstract}
Abstrak
Upaya mewujudkan keamanan pangan dilakukan dengan menerapkan higiene perorangan dan sanitasi lingkungan yang baik.Tujuan penelitian yaitu menggambarkan praktik higiene perorangan dan sanitasi warung pecel tumpang di Kediri.Penelitianobservasional dengan desain cross sectionaldilakukan pada 20 sampel. Data disajikan pada tabel dan dianalisis secara deskriptif. Praktik higiene perorangan cukup (80\%), kondisi lokasi dan bangunan baik (50\%), tempat pembuangan sampah buruk (50\%), fasilitas sanitasi buruk (50\%), sanitasi peralatan baik (100\%), dan sumber air cukup (90\%). Beberapa variabel penelitian menunjukkan sanitasi warung yang buruk yaitu tempat pembuangan sampah dan fasilitas sanitasi.
\end{abstract}

Kata Kunci: higiene perorangan, sanitasi warung, pecel tumpang

\section{PENDAHULUAN}

Makanan merupakan salah satu bagian yang penting untuk kesehatan manusia, ${ }^{1}$ dimana makanan digunakan untuk memenuhi kebutuhan tubuh, jaringan tubuh, serta menghasilkan energi untuk aktifitas tubuh. ${ }^{2}$ Makanan yang dibutuhkan manusia tidak hanya dilihat dari segi kuantitas atau jumlahnya melainkan juga dari segi kualitas. Salah satu contoh makanan

1 Gading Giovani Putri adalah Bagian Staff Pengajar S1 Kesehatan Masyarakat, Institut Ilmu Kesehatan Bhakti Wiyata Kediri

2 Yoanita Indra Kumala Dewi adalah Bagian Staff Pengajar d3 Analisis Kesehatan, Institut Ilmu Kesehatan Bhakti Wiyata Kediri 
memenuhi standar keamanan pangan.Oleh sebab itu, masyarakat sangat perlu memperhatikan keamanan pangan yang dikonsumsinya.

Makanan yang dikonsumsi oleh masyarakat dapat terkontaminasi mikroorganisme patogen yaitu mikroorganisme yang dapat menimbulkan penyakit dan juga bahan kimia berbahaya. Kontaminasi mikroorganisme dalam makanan dapat disebabkan oleh pengelolaan dan penyajian makanan yang tidak higienis serta sanitasi lingkungan yang buruk.Penyakit atau gangguan kesehatan yang timbul akibat adanya kontaminasi dalam makanan biasa disebut penyakit bawaan makanan (food borne disease). Penyakit ini mengganggu saluran pencernaan manusia dengan gejala yang ditimbulkan seperti mual, muntah dan diare. ${ }^{3}$ Angka kejadian diare di masyarakat masih cukup tinggi. Berdasarkan data profil kesehatan Jawa Timur diketahui bahwa pada Tahun 2013 kejadian diare di Jawa Timur mencapai $118,39 \%$, kemudian pada tahun 2014 menurun menjadi 106\%. Penurunan angka diare tersebut tidak dapat diremehkan mengingat penyakit diare merupakan penyakit yang cukup berbahaya terutama bagi anak-anak.

Pecel tumpang merupakan salah satu makanan khas kota Kediri yang terbuat dari campuran tempe segar dan tempe busuk serta penambahan bumbubumbu lainnya. ${ }^{5}$ Berdasarkan studi pendahuluan yang dilakukan oleh peneliti diperoleh informasi bahwa bahan baku utama pembuatan pecel tumpang adalah tempe busuk karena mempunyai rasa yang khas. Hasil pengamatan awal juga menunjukkan sebagian besar lokasi penjualan pecel tumpang banyak yang tidak dilengkapi dengan sarana sanitasi.Makanan tradisional seperti pecel tumpang pada umumnya memiliki kelemahan dalam hal keamanannya terhadap bahaya mikrobiologi karena rendahnya mutu bahan baku dan belum diterapkannya higiene perorangan penjamah makanan serta sanitasi lingkungan yang kurang memenuhi syarat. ${ }^{6}$

Berdasarkan latar belakang yang telah dipaparkan diatas, maka peneliti tertarik untuk melakukan penelitian tentang higiene perorangan dan sanitasi warung pecel tumpang di Kota Kediri.Penelitian ini bertujuan untuk memberikan gambaran tentang praktik higiene perorangan penjual dan kondisi sanitasi warung pecel tumpang di Kota Kediri.

\section{METODE PENELITIAN}

Penelitian ini merupakan penelitian observasional dengan desain cross sectional karena penelitian ini mengamati dan mengukur variabel penelitian tanpa memberikan perlakuan atau intervensi.

Populasi dalam penelitianini adalah seluruh penjual pecel tumpang yang berjualan di Kecamatan Mojoroto Kota Kediri.Penelitian ini mengambil seluruh populasi untuk dijadikan responden penelitian yaitu sebanyak 20 orang penjual pecel tumpang.

Pengumpulan data penelitian melalui kegiatan observasi lapangan dan wawancara kepada responden penelitian. Instrumen pengumpulan data yang digunakan yaitu lembar observasi berupa check list. Variabel penelitian ini yaitu karakteristik individu, praktik higiene perorangan, dan sanitasi warung pecel tumpang yang terdiri dari kondisi lokasi dan bangunan, kondisi tempat pembuangan sampah dan limbah cair, kondisi fasilitas sanitasi, kondisi sanitasi peralatan, dan 
kondisi sumber air bersih.Data disajikan dalam bentuk tabel dan dianalisis secara deskriptif.

\section{HASIL DAN PEMBAHASAN}

\section{Karakteristik Responden}

Berdasarkan Tabel 1.diketahui bahwa penjual pecel tumpang semuanya berjenis kelamin perempuan (100\%), berumur 41-60 tahun (65\%), sebagai pemilik warung $(100 \%)$, dan telah bekerja sebagai penjual pecel tumpang selama 1-5 tahun (60\%).

Pada umumnya responden selain bekerja sebagai penjual pecel tumpang juga merupakan pengolah atau sebagai juru masak pecel tumpang.Pekerjaan sebagai penjual pecel tumpang dilakukan untuk menambah penghasilan keluarga.Semua responden merupakan pemilik warung sehingga semua pelaksanaan persyaratan pengelolaan makanan yang berkaitan dengan higiene sanitasi makanan sesuai dengan tingkat pengetahuan responden itu sendiri.

\section{Praktik Higiene Perorangan}

Berdasarkan hasil penelitian pada Tabel 2.diketahui bahwa sebagian besar praktik higiene perorangan pada penjual pecel tumpang adalah cukup (80\%). Hasil penelitian terhadap 20 responden menunjukkan bahwa sebanyak 16 responden (80\%) penjual pecel tumpang memiliki higiene perorangan yang cukup dan sebanyak 4 responden (20\%) memiliki higiene perorangan yang buruk.

Tabel 1. Karakteristik Responden

\begin{tabular}{|c|c|c|c|}
\hline No. & Karakteristik Penjual & $\mathbf{n}$ & $\%$ \\
\hline \multirow[t]{5}{*}{1.} & Umur & & \\
\hline & $\leq 20$ tahun & 0 & 0 \\
\hline & 21-40 tahun & 7 & 35 \\
\hline & 41-60 tahun & 13 & 65 \\
\hline & $>60$ tahun & 0 & 0 \\
\hline \multirow[t]{3}{*}{2.} & Jenis kelamin & & \\
\hline & Laki-laki & 0 & 0 \\
\hline & Perempuan & 20 & 100 \\
\hline \multirow[t]{3}{*}{3.} & Status kepemilikan warung & & \\
\hline & Pemilik & 20 & 100 \\
\hline & Pegawai & 0 & 0 \\
\hline \multirow[t]{4}{*}{4.} & Lama kerja & & \\
\hline & $<1$ tahun & 0 & 0 \\
\hline & 1-5 tahun & 12 & 60 \\
\hline & $\geq 5$ tahun & 8 & 40 \\
\hline
\end{tabular}

Sumber: Data Primer Tahun 2017 
Praktik higiene perorangan dilakukan responden sesuai dengan pengetahuan sendiri, pada umumnya responden banyak yang tidak terlalu memperhatikan karena mereka lebih mengutamakan rasa makanan. Praktikhigiene perorangan yang buruk akan meningkatkan risiko kontaminasi bakteri patogen seperti Eschericia coli pada makanan. Salah satu komponen higiene perorangan adalah status kesehatan pengelola makanan.Setiap pengelola makanan harus bebas penyakit menular. Ada tiga kelompok penderita penyakit yang tidak boleh dilibatkan dalam penanganan makanan seperti ISPA, pencernaan dan penyakit kulit, karena penyakit ini dapat menular kepada orang lain melalui makanan yang diolah ataupun yang disajikan oleh penderita7 ${ }^{7}$. Oleh sebab itu sebaiknya para pengelola makanan melakukan pemeriksaan rutin setiap 6 bulan sekali. Hasil wawancara menunjukkan bahwa semua responden tidak pernah melakukan pemeriksaan rutin setiap 6 bulan sekali, responden penelitian akan melakukan pemeriksaan kesehatan apabila tubuh mereka sudah menunjukkan gejala sakit.

Hasil observasi menunjukkan bahwa banyak penjual pecel tumpang yang tidak menggunakan sarung tangan ketika menyajikan makanan.Penggunaan sarung tangan dianggap menghambat kerja para penjual dan juga mengganggu kenyamanan saat bekerja.Penelitian serupa yang dilakukan Tahun 2003 di Depok menyatakan bahwa tangan merupakan sumber kontaminan yang cukup berpengaruh terhadap kebersihan bahan makanan. Sentuhan tangan merupakan penyebab yang paling umum terjadinya pencemaran pada makanan ${ }^{8}$.

Kebiasaan mencuci

tanganmenggunakan sabun dan air mengalir terutama sebelum mengelola makanan dan setelah dari toilet juga mempengaruhi kontaminasi virus atau bakteri pada makanan yang dapat menularkan penyakit. Kuman penyakit yang tidak terlihat tanpa sadar membuat masyarakat sering meremehkan keberadaannya ${ }^{9}$.

\section{Sanitasi Warung Pecel Tumpang}

Tabel 2.menunjukkan kondisi sanitasi warung pecel tumpang yang meliputi kondisi lokasi dan bangunan, kondisi tempat pembuangan sampah dan limbah cair, kondisi fasilitas sanitasi, kondisi sanitasi peralatan, dan kondisi sumber air bersih. Berikut adalah pembahasan dari masing-masing variable penelitian:

\section{a. Lokasi dan bangunan}

Hasil penelitian terhadap 20 responden menunjukkan bahwa sebanyak 10 responden (50\%) memiliki lokasi dan bangunan yang baik, sebanyak 5 responden (25\%) memiliki lokasi dan bangunan yang cukup, dan sebanyak 5 responden (25\%) memiliki lokasi dan bangunan yang buruk. Hasil observasi menunjukkan bahwa sebagian besar penjual pecel tumpang menempati bangunan tidak permanen seperti kaki lima dan lesehan. Fasilitas bangunan berperan penting dalam menunjang proses sanitasi. Lokasi dan bangunan harus dirancang berdasarkan prinsip sanitasi untuk mencegah agar binatang pembawa pes tidak bersarang. Bangunan sebaiknya tidak terbuat dari kayu karena dapat menjadi media pembiakan mikroba. Sistem ventilasi dan pencahayaan yang baik akan mengurangi terjadinya pencemaran udara dalam ruangan ${ }^{10}$.

\section{b. Tempat pembuangan sampah dan limbah cair}

Kondisi tempat pembuangan sampah dan limbah cair yang diamati 
pada 20 warung pecel tumpang menunjukkan sebanyak 12 warung mempunyai kondisi tempat pembuangan sampah dan limbah cair yang buruk $(60,0 \%)$, sebanyak 2 warung memiliki kondisi yang cukup (10\%), dan sebanyak 6 warung memiliki kondisi yang baik
(30,0\%). Hasil pengamatan menemukan bahwa sebagian besar sampah berasal dari sisa-sisa makanan.Tempat sampah yang dimiliki penjual tidak memiliki tutup, tidak ada pemisahan jenis sampah, serta ada juga yang menggunakan kantong plastik untuk tempat sampah.

Tabel 2. Higiene Perorangan dan Sanitasi Warung Pecel Tumpang

\begin{tabular}{|c|c|c|c|}
\hline No. & Variabel & $\mathbf{n}$ & $\%$ \\
\hline \multirow[t]{4}{*}{1.} & Higiene Perorangan & & \\
\hline & Buruk & 4 & 20 \\
\hline & Cukup & 16 & 80 \\
\hline & Baik & 0 & 0 \\
\hline \multirow[t]{4}{*}{2.} & Lokasi dan Bangunan & & \\
\hline & Buruk & 5 & 25 \\
\hline & Cukup & 5 & 25 \\
\hline & Baik & 10 & 50 \\
\hline \multirow[t]{4}{*}{3.} & Tempat Pembuangan Sampah dan Limbah Cair & & \\
\hline & Buruk & 12 & 60 \\
\hline & Cukup & 2 & 10 \\
\hline & Baik & 6 & 30 \\
\hline \multirow[t]{4}{*}{4.} & Fasilitas Sanitasi & & \\
\hline & Buruk & 10 & 10 \\
\hline & Cukup & 3 & 15 \\
\hline & Baik & 7 & 35 \\
\hline \multirow[t]{4}{*}{5.} & Sanitasi Peralatan & & \\
\hline & Buruk & 0 & 0 \\
\hline & Cukup & 0 & 0 \\
\hline & Baik & 20 & 100 \\
\hline \multirow[t]{4}{*}{6.} & Sumber Air Bersih & & \\
\hline & Buruk & 0 & 0 \\
\hline & Cukup & 18 & 90 \\
\hline & Baik & 2 & 10 \\
\hline
\end{tabular}

Sumber: Data Primer Tahun 2017

Kantong plastik dipilih responden karena dianggap paling praktis dan tidak memakan tempat serta pengeluaran biaya untuk membeli tempat sampah. Tempat sampah yang terbuka akan lebih mudah dihinggapi lalat maupun serangga lainnya, selain itu juga akan menimbulkan bau yang mengganggu manusia di sekitarnya.

\section{c. Fasilitas sanitasi}

Kondisi fasilitas sanitasi dari hasil pengamatan pada 20 warung pecel tumpang menunjukkan sebagian besar warung memiliki fasilitas sanitasi yang buruk yaitu sebanyak 10 warung (50\%),sebanyak 3 warung dengan kondisi yang cukup (15\%), dan sebanyak 7 warung dengan kondisi yang baik 
(35\%).Hasilpengamatan peneliti sebagian besar pedagang tidak mempunyai fasilitas cuci tangan dengan air yang mengalir.Tempat cuci tangan yang dimiliki responden berupa air yang ditampung di ember dan tidak tertutup. Sebelum menyediakan makanan para penjual mencelupkan tangan ke ember terlebih dahulu kemudian dikeringkan dengan lap kain bahkan ada juga yang tidak mencuci tangan sama sekali. Air mengalir merupakan sarana mencuci tangan yang baik, karena kuman yang menempel akan ikut terbuang bersama aliran air, berbeda dengan air yang ada diember, kuman akan tetap ada didalam air yang ada diember8.

\section{d. Sanitasi peralatan}

Berdasarkan Tabel 2.diketahui bahwa kondisi sanitasi peralatan dari 20 warung pecel tumpang adalah baik (100\%). Peralatan yang digunakan responden terbuat dari bahan yang kedap air, memiliki tutup dan terpisah antara jenis makanan yang berbeda seperti nasi, sayuran, lauk pauk, dan sambal. Proses pencucian alat makan sebagian besar dilakukan menggunakan sabun cuci khusus piring, namun tidak dibilas dengan air mengalir. Air untuk mencuci peralatan makan pada umumnya diletakkan di dalam ember atau baskom ${ }^{8}$. Peralatan yang dicuci akan dimasukkan ke dalam ember tersebut kemudian di keringkan menggunakan lap.

Pencucian peralatan makan akan lebih baik jika dilakukan segera untuk mencegah pertumbuhan bakteri12.Pemisahan penggunaan peralatan dalam pengelolaan makanan harus diperhatikan, seperti pisau yang digunakan untuk bahan makanan harus dipisah dengan yang digunakan untuk makanan jadi, centong untuk nasi harus dipisah dengan yang untuk centong sambal tumpang dan lain sebagainya. Sendok untuk mencicipi juga harus dipisah dengan sendok untuk mengolah makanan, untuk menghindari terjadinya kontaminasi makanan dari pengolah makanan.

Peralatan yang digunakan dalam pengelolaan makanan harus dibersihkan untuk mencegah kontaminasi silang pada makanan, dimana peralatan dapur untuk pengolahan dan untuk penyajian merupakan sumber kontaminan potensial bagi makanan ${ }^{7}$.Hasil temuan penelitian di Depok menunjukkan kandungan E.coli piring yang digunakan oleh penjual gado-gado adalah sangat tinggi yaitu $>100$ koloni/ $\mathrm{ml}^{8}$.Hal tersebut menginformasikan kepada masyarakat bahwa sumber kontaminasi bakteri pada makanan tidak hanya berasal dari makanan itu sendiri melainkan juga dari peralatan makan yang digunakan.

\section{e. Sumber air bersih}

Kondisi sumber air bersih dari 20 warung pecel tumpang yang diamati adalah bervariasi, sebagian besar warung memiliki kondisi sumber air bersih yang cukup yaitu sebanyak 18 warung $(90,0 \%)$, sebanyak 2 warung memiliki kondisi sumber air bersih yang baik $(10,0 \%)$, dan tidak ada warung yang memiliki sumber air yang tidak bersih. Berdasarkan hasil pengamatan diketahui bahwa air bersih yang digunakan untuk pengelolaan makanan pada warung pecel tumpang di Kota Kediri memenuhi syarat kualitas fisik seperti tidak berwarna, tidak berbau, dan tidak berasa, namun untuk kualitas fisik maupun kualitas kimia dari air bersih yang digunakan masih belum dapat diketahui karena penelitian ini tidak melakukan pemeriksaan tersebut. Penggunaan air dalam pengelolaan makanan perlu mendapatkan perhatian khusus karena 
berperan besar dalam semua tahapan mulai dari proses persiapan pengolahan, pemasakan makanan hingga penyajian makanan. Air yang dapat digunakan dalam proses pengelolaan makanan harus memenuhi syarat untuk dapat diminum, yaitu bebas dari bakteri, bersih dan jernih, tidak berwarna dan tidak berbau ${ }^{10}$.Air yang terkontaminasi berperan untuk menularkan bakteri pathogen pada makanan yang diolah ${ }^{8}$. Hasil wawancara menunjukkan bahwa air bersih yang digunakan para responden mencukupi kegiatan pengelolaan makanan pada warung pecel tumpang di Kediri.

\section{SIMPULAN DAN SARAN}

Berdasarkan hasil analisis statistik, maka kesimpulan dari penelitian ini adalah sebagai berikut:

1. Sebagian besar penjual pecel tumpang adalah perempuan (100\%), berumur 41-60 tahun (65\%), sebagai pemilik warung (100\%), lama kerja 1-5 tahun $(60 \%)$.

2. Praktik hygiene perorangan pada penjual pecel tumpang adalah cukup $(80 \%)$.

3. Kondisi lokasi dan bangunan (50\%) dan kondisi sanitasi peralatan (100\%) adalah baik.

4. Kondisi sumber air bersih adalah cukup (90\%).

5. Kondisi tempat pembuangan sampah dan limbah cair (50\%) dan kondisi fasilitas sanitasi (50\%) adalah buruk.

Saran yang dapat disampaikan berdasarkan kesimpulan dari penelitian ini adalah sebagai berikut:

1. Penjual pecel tumpang meningkatkan praktik hygiene perorangan selama bekerja seperti menggunakan sarung tangan dan mencuci tangan sebelum menjamah makanan.

2. Penjual pecel tumpang perlu memperbaiki kondisi sanitasi warung yang buruk seperti tempat pembuangan sampah limbah cair dan fasilitas sanitasi.

3. Petugas kesehatan perlu melakukan pembinaan kepada para penjual pecel tumpang seperti mengadakan kursus tentang higiene sanitasi makanan untuk mewujudkan keamanan pangan di masyarakat.

4. Penelitian selanjutnya diharapkan dapat menganalisis hubungan higiene perorangan dan sanitasi warung pecel tumpang dengan keberadaan mikroorganisme pathogen atau bahan kimia dalam pecel tumpang.

\section{DAFTAR RUJUKAN}

[1] Chandra B. Pengantar Kesehatan Lingkungan. Jakarta: EGC; 2006.

[2] Sukamto dan Supardi. Mikrobiologi Dalam Pengolahan dan Keamanan Pangan. Bandung: Alumni; 1999.

[3] Supraptini. Kejadian Keracunan Makanan dan Penyebabnya di Indonesia 1995-2000. Ekologi Kesehatan. 2002;1:127-35.

[4] Dinkes Provinsi Jatim. Profil Kesehatan Provinsi Jawa Timur. 2014.

[5] Soewitomo S. 500 Resep Makanan Terfavorit. Jakarta: PT Gramedia Pustaka Utama; 2011.

[6] Munir, Franklin N. Tata Laksana Higiene Hidangan, Keracunan Hidangan, Jenis Bakteria. 2007;

[7] Purnawijayanti HA. Sanitasi Higiene dan Keselamatan Kerja Dalam Pengolahan Makanan. Yogyakarta: KANISIUS; 2001. 
[8] Susana D, Hartono B. Pemantauan Kualitas Makanan Ketoprak dan Gado-Gado di Lingkungan Kampus UI Depok Melalui Pemeriksaan Bakteriologis. Makara Seri Kesehatan. 2013;7 (1): 21-29.

[9] Murwaningsih S. Penerapan Cuci Tangan Pakai Sabun di SDN II Kota Karang Bandar Lampung. Jurnal Kesehatan. 2016;VII:148-55.

[10] Arisman. Buku Ajar Ilmu Gizi Keracunan Makanan. Jakarta: EGC; 2009.
[11] Adha HN, Yuliana Y, Waryono W. Pengelolaan Sanitasi di Kawasan Pedagang Makanan Kaki Lima Kota Payakumbuh. Journal Home Economic and Tourism.2016; 11(1)

[12] Cahyaningsih CT, Kushadiwijaya H, Tholib A. Hubungan Higiene Sanitasi dan Perilaku Penjamah Makanan Dengan Kualitas Bakteriologis Peralatan Makan di Warung Makan. Berita Kedokteran Masyarakat. 2009; 25 (4): 180-188 